See discussions, stats, and author profiles for this publication at: https://www.researchgate.net/publication/329336606

\title{
The Validity of Entrepreneurship Module-Based Products in Vocational Education
}

Conference Paper · July 2018

CITATIONS

0

3 authors, including:

Syaiful Islami

Situs Resmi Universitas Negeri Padang

11 PUBLICATIONS 8 CITATIONS

SEE PROFILE

Some of the authors of this publication are also working on these related projects:

Project Teaching and Learning View project

Project Designing learning stages of production based entrepreneurship learning View project
READS

12 


\title{
The Validity of Entrepreneurship Module-Based Products in Vocational Education
}

\author{
Asmar Yulastri ${ }^{1}$, Syaiful Islami ${ }^{2}$, Ganefri $^{3}$ \\ ${ }^{1}$ Fakultas Pariwisata dan Perhotelan \\ ${ }^{2,3}$ Fakultas Teknik \\ Universitas Negeri Padang \\ Padang, Indonesia \\ a_yulastri@yahoo.co.id
}

\begin{abstract}
This article aims to reveal the validity of the entrepreneurship module based-product in vocational education. Based on the observation, the existing problem is the unavailability of entrepreneurship module that causes the learning process has not been maximized. The method used is Research and Development with development model Analysis, Design, Development, Implementation, and Evaluation (ADDIE). The validation process is accompanied by a discussion or direct interview with the expert on improvements to be made. The design of a product-based entrepreneurial module is consulted first with experts or experts and counselors. Then, the design is judged by the competent people who have understood the module development principle. Data collection instrument in the form of a questionnaire. The results obtained are a valid product-based entrepreneurial module on aspects of content, aspects of the format and presentation aspects.
\end{abstract}

Keywords—validity; entrepreneurship; module based products

\section{INTRODUCTION}

Vocational education is required to produce competent workforce in order to increase productivity and efficiency, as well as preparedness for MEA competition and international labor market competition in globalization era [1].

One of the subjects in vocational education at higher education in entrepreneurship. The objective of entrepreneurship subject in Universitas Negeri Padang on the year 2015 is to provide knowledge and cultivate entrepreneurial spirit, needs analysis, market opportunity, business planning, feasibility study, production management, human resource marketing, and business development planning [2]. Entrepreneurship education students to be responsible and become an entrepreneur and able to contribute in sustainable economic development [3]. The goal is expected to provide graduates who have an entrepreneurial spirit so as to reduce educated unemployment.

According to Fiet educators must find difficulties in teaching entrepreneurship lectures to students, both in higher education and in school [4]. Student tend to complain that entrepreneurial theory is boring, entrepreneurial lectures are boring, as well as all entrepreneurial theories and lectures can be irrelevant to the conditions occurring in the field. Educators who are boring and irrelevant in the eyes of the students make the students less motivated to learn. Students may not have realized that entrepreneurial learning can be very interesting. Unfortunately, the reality of this time the entrepreneurial learning process was very boring. It happens because what educators will teach is easy for students to predict [4].

Based on the results of preliminary observations conducted, found constraints faced by lecturers in entrepreneurship teaching. Constraints such as time constraints in entrepreneurial face-to-face lectures so that the material submitted becomes constrained. Student independence is very weak in learning. This is seen during the discussion there are many passive students during the learning process. They look busy with their own activities when the learning process takes place. Therefore, it takes learning media that support the learning process to be more effective, modules is alternative in learning for self-learning methods for students[5],module provides benefits for students of different types and frequencies for each student, provides stimulus dialogue and raises awareness in learning [6]

Module as one of the teaching media owned by lecturers is still general because only theoretical. Modules used are still less support for entrepreneurial learning process. The learning process is still focused on the mastery of theory. The provision of skills is also fragmentary and not comprehensive in the form of exercises that do not produce a business plan that can later is used as a reference in opening a new business. As a result implementation of science in the learning process has not done perfectly, and module can help students in learning anytime and anywhere and with student modules can also improve learning outcomes[7]

Here is the percentage of entrepreneurship learning outcomes of students of Electrical Engineering Education Program of the academic year 2014/2015.

TABLE I. The PeRCENTAGE OF STUdENT ENTREPRENEURSHIP LEARNING OUTCOMES

\begin{tabular}{|l|l|l|}
\hline \multicolumn{1}{|c|}{ Student values } & Number of students & Percentage \% \\
\hline A & 13 & 14,44 \\
\hline A- & 8 & 8,89 \\
\hline B + & 4 & 4,44 \\
\hline B & 11 & 12,22 \\
\hline
\end{tabular}




\begin{tabular}{|l|l|l|}
\hline \multicolumn{1}{|c|}{ Student values } & Number of students & Percentage \% \\
\hline B- & 3 & 3,33 \\
\hline C + & 13 & 14,44 \\
\hline C & 20 & 22,22 \\
\hline C- & 8 & 8,89 \\
\hline D & 2 & 2,22 \\
\hline E & 8 & 8,89 \\
\hline Total & $\mathbf{9 0}$ & $\mathbf{1 0 0}$ \\
\hline
\end{tabular}

Table I shows that the students' learning outcomes have not been maximized. When interviewed, some students mentioned that entrepreneurship lesson was boring because it contained only predictable theories so that students' interest and motivation became less. Another problem is that students are less creative to learn entrepreneurship. Therefore, it is demanded something that interest, motivation, and creativity of students to teach entrepreneurship.

A well-executed learning process is supported by wellchosen learning media. One suitable medium in the entrepreneurial learning process is the module. A module is a teaching material that contains material, methods, limitations, and evaluations that are arranged systematically and appealingly. Modules can be used independently because in the module there are examples that support material clarity, practice and tasks questions, as well as summary and evaluation (self-instructional). Learning materials contained in the module are packaged in a unit of intact activity so that it is easy to be studied thoroughly (self-contained). The module also has a stand-alone characteristic, that is not dependent on other media; in accordance with the development of science and technology, as well as flexible (adaptive) and friendly with users (user-friendly), and help ease the user to respond or access [8].

Taking into account the characteristics of the learning process, especially entrepreneurial learning, the development of product-based modules is quite potential to meet the demands of such learning. Product-based modules can lead learners to systematic and standardized work procedures to create or complete a product (goods or services), through actual production/work processes [9]. The entrepreneurship subject matter, according to the syllabus, has five subjects. These topics are the first topic on introductory entrepreneurship, the second topic on the leadership role in entrepreneurship, third topic on the management role in entrepreneurship, fourth topic about the business idea and business opportunity analysis, and the fifth topic about the business plan.

The advantages of product-based modules are to support existing teaching materials, giving students the opportunity to learn independently with the concepts described in the module, and to improve student competence, and to grow student entrepreneurship spirit [10]. In addition, product-based modules in entrepreneurship courses in the Electrical Engineering Education course are not yet available.

So the product-based module is expected to lead the students to produce a business plan from the student learning process. During the learning process, students are required to produce the good business plan and in accordance with the standard. In the learning process by using this product-based module, students are directed to be able to create a business plan. The business plan is expected to be implemented. Although only required to make a business plan is not closed also the possibility of students generate many business plans for the learning of this entrepreneurship in accordance with the interests and expertise of the students themselves.

Based on these facts, researchers want to improve entrepreneurial learning by designing a module that can help lecturers develop learning strategies in an effort to help students to be more creative. The author will develop productbased modules specifically designed for entrepreneurial learning. The use of product-based modules on entrepreneurial learning is expected to make students more creative and independent in learning so as to increase the activity and learning outcomes, module can improve student engagement in the learning [11]

\section{METHOD}

The development procedure in this study follows the sequence of activities in the ADDIE model presented by Branch [12]

\section{A. Analysis}

The analysis includes the needs analysis in the development of entrepreneurship module based-product. Needs analysis has several steps that are done that is:

\section{1) Curriculum Analysis}

Curriculum analysis refers to the synopsis and syllabus of entrepreneurship courses so that the resulting module does not deviate from the learning outcome.

\section{2) Student Analysis}

The subject of this research is the students of Electrical Engineering Education in the odd semester of academic year 2016/2017. Students who take entrepreneurship courses have an 18-20 year age range. At that age learners basically have been able to analyze and create their own hypotheses to a problem. Where, according to Anderson, each category in Bloom's Taxonomy revision, "the student at that age lies in the create category in which learners have been able to design, build, plan, produce, discover, update, refine, strengthen, beautify, transform [13].

\section{B. Design}

This stage verifies the form of troubleshooting to be performed and determines the appropriate testing method. This stage includes the translation of needs and learning objectives into specific module-making objectives. This stage designs a product-based entrepreneurial module according to needs analysis. In addition, at this stage also designed instruments to perform product validation instruments, instruments of practicality, instruments of effectiveness and instrument validation instruments. 


\section{Development}

This development stage generates and validates productbased entrepreneurial modules. The validation process is accompanied by a discussion or direct interview with the expert on improvements to be made. The design of a productbased entrepreneurial module is consulted first with experts or experts and counselors. Then, the design is assessed by the people who are competent (validator) who has understood the principles of module development, the lecturer FT-UNP Postgraduate and lecturer entrepreneurship courses.

Validations of this module there are three kinds, namely as follows.

1) Content validity, i.e. whether the module has been designed in accordance with the course syllabus.

2) Format validity, i.e. the suitability of module components with predefined elements.

3) The validity of presentation that is valid with respect to the use of language, writing, drawing, and appearance in making learning media.

\section{Implementation}

Implementation stage is done by preparing the learning environment and student involvement in lectures consisting of preparation of lecturers and students. Students are given a product-based entrepreneurship module to find out the practicalities and effectiveness of using the module.

Design lecture implementation using one group pretestposttest. The pretest is given at the beginning of the lecture. Posttest is given at the end of the lecture.

\section{E. Evaluation}

This stage assesses the quality of product development and development process both before and after implementation, by determining the evaluation criteria, determining the instrument, and evaluating.

The statistical procedure that shows the popular logical validity is the validity of the test content based on the content validity of the content. One of the statistics that shows the validity of the content of item is as proposed by Aiken. Aiken has formulated the Aiken's V formula for calculating the Content Validity Coefficient based on the research results of a panel of experts as much as $\mathrm{n}$ on a product development module of entrepreneurship based on products in terms of the extent to which the item represents the measured constants [14]. In this case, representing the measured constituent means the relevant item is relevant to its performance indicator since the behavioral indicator is the operational translation of the attribute being measured. Assessment is done by giving a number between 1 (ie not highly representative or highly irrelevant) to 4 (ie very representative or highly relevant).

The Aiken Statistics V can be formulated as follows [14]:

$$
\mathrm{V}=\sum \mathrm{s} /[\mathrm{n}(\mathrm{c}-1)]
$$

Description:

$$
\mathrm{s} \quad=\mathrm{r}-1 \mathrm{o}
$$

lo $=$ the lowest validity score (in this case $=1$ )

c $\quad=$ highest validity score (in this case $=4$ )

$\mathrm{r} \quad=$ numbers given by an appraiser.

The results of Aiken calculations ranged from 0 to 1 and the numbers 0.6 can be interpreted to have a high enough coefficient. The value of $\mathrm{V} 0.6$ and above is expressed in a valid category.

\section{RESULTS AND DISCUSSION}

The validity test data was obtained from the validator's response to the validity of the product-based module.

\section{A. Content Validation}

In this validation phase, the product-based module undergoes several fixes based on suggestions from the validator.

TABLE II. THE VALIDATOR'S ASSESSMENT OF CONTENT

\begin{tabular}{|c|l|l|l|}
\hline No & Indicator & Aiken's V & Category \\
\hline 1 & Indicator 1 & 0,900 & Valid \\
\hline 2 & Indicator 2 & 0,893 & Valid \\
\hline \multicolumn{2}{|c|}{ Total } & 0,897 & Valid \\
\hline
\end{tabular}

Based on Table II it can be concluded that the Content assessment on the product-based entrepreneurship module is Valid with Aiken's V value of 0.897. In the first indicator the value of Aiken's V of 0.900 with the category Valid and on the second indicator Aiken's V value of 0.893 with the category Valid.

\section{B. Format Validation}

At the format validation stage, the product-based entrepreneurship module undergoes several fixes based on suggestions from the validator.

TABLE III. THE VALIDATOR'S ASSESSMENT OF FORMAT

\begin{tabular}{|c|l|l|l|}
\hline No & Indicator & \multicolumn{1}{|c|}{ Aiken's V } & Category \\
\hline 1 & Indicator 1 & 0,833 & Valid \\
\hline 2 & Indicator 2 & 0,894 & Valid \\
\hline \multicolumn{2}{|c|}{ Total } & 0,864 & Valid \\
\hline
\end{tabular}

Based on Table III it can be concluded that the valuation of the product-based entrepreneurship module format is Valid with Aiken's V value of 0.864 . In the first indicator the value of Aiken's V of 0.833 with the category Valid and on the second indicator Aiken's V value of 0.894 with the category Valid.

\section{Validation of Presentation}

In the presentation validation stage, the product-based module undergoes several fixes based on suggestions from the validator.

TABLE IV. The VALIDATOR'S ASSESSMENT OF PRESENTATION

\begin{tabular}{|l|l|l|l|}
\hline No & Indicator & Aiken's V & Category \\
\hline
\end{tabular}




\begin{tabular}{|l|l|l|l|}
\hline 1 & Indicator 1 & 0,933 & Valid \\
\hline 2 & Indicator 2 & 0,833 & Valid \\
\hline \multicolumn{2}{|c|}{ Total } & 0,883 & Valid \\
\hline
\end{tabular}

Based on Table 4 it can be concluded that the assessment of the product-based entrepreneurship module presentation is Valid with Aiken's V value of 0.883 . In the first indicator the value of Aiken's $\mathrm{V}$ is 0.933 with the valid category and on the second indicator Aiken's $\mathrm{V}$ value of 0.833 with the valid category.

Based on the suggestions given validator, then revised the module so as to obtain a product-based entrepreneurship module valid and feasible to be tested as a learning media on entrepreneurship courses.

\section{DISCUSSION}

Based on the results of the research, a validated productbased entrepreneurship module has fulfilled the requirements of a good module, which comprises module components in accordance with indicators, conformity of the content in the learning module, clarity of instructions, the preparation of the material in the learning module, the suitability of the format, display and language on the learning module to make it easier for students to understand entrepreneurship learning and applying it.

Valid means it has provided accurate information about the developed teaching materials [15]. Validation of the productbased entrepreneurship module in the entrepreneurship course is conducted by a validator consisting of three experts. All of the validators are experts in the field of study, therefore the validation of this result has been accountable. The three aspects of validation when summed the score of validity values obtained from each validator then obtained Aiken's V with an average of 0.881 . This earned value is in a valid category.

In the content of the module, the validator stated that the product-based entrepreneurship module developed as one of the learning media has been in accordance with the curriculum, and learning outcomes that must be achieved by the students, including the suitability of the module contents, clarity of instructions, the preparation of the material, the suitability between the material practiced with the media learning, image suitability with the material being practiced, display images and text so as to facilitate students to understand the learning materials. The validation value of the content of entrepreneurship module based on the developed product is 0.897 with the valid category. Content validation is a requirement regarding the process of finding the correct concepts and in accordance with the applicable curriculum. Valid validation results for content validation indicate that the product-based entrepreneurship module developed has been well-suited to the current curriculum.

In aspect format, validation value from validator also gets the valid value that is 0,864 is categorized valid. The validity of the module format is the suitability of module components with predefined elements. Based on the validity value obtained from the validator it can be concluded that the product-based entrepreneurship module developed has been in accordance with the requirements of the construction of learning module.

The presentation validity is an indicator of validity with respect to the use of language, writing, drawing, and appearance in the manufacturing of product-based entrepreneurial modules. The validation value of the productbased entrepreneurship module presentation is 0.883 with the valid category. Thus, the validation of the presentation also obtains a valid value. This indicates that the product-based entrepreneurship module developed has been perfectly in line with the technical requirements of a learning module.

\section{CONCLUSION}

Research on the development of entrepreneurship module based on product is developed by using ADDIE model, which consists of analysis, design, development, and evaluation. This entrepreneurship module consists of five topics of learning: the first topic on introductory entrepreneurship, the second topic on the leadership role in entrepreneurship, third topic of the management role in entrepreneurship, fourth topic about the business idea and business opportunity analysis, and the fifth topic about the business plan.

The validity of the product-based entrepreneurship module developed meets the content, format, and presentation aspects. So it can be concluded that the product-based entrepreneurship module developed is valid for use in learning.

\section{References}

[1] Ganefri, "The development of production-based learning approach to entrepreneurial spirit for engineering students," Asian Soc. Sci., vol. 9 , no. 12 , pp. $162-167,2013$

[2] UNP, Pedoman Akademik UNP. Padang: Universitas Negeri Padang, 2015.

[3] M. Raposo and A. Paço, "Entrepreneurship education: relationship between education and entrepreneurial activity," Psicothema, vol. 23, no. 3, pp. 453-457, 2011.

[4] J. O. Fiet, "The pedagogical side of entrepreneurship theory," J. Bus. Ventur., no. January 2012, pp. 101-107, 2015

[5] J. W. J. Robinson and W. B. Crittenden, "Learning Modules: A Concept for Extension Educators?," Journal of Extension (Winter). pp. 35-44, 1972.

[6] M. Hobbs and N. Zealand, "Studies in Self-Access Learning Journal, 6 (1), 13-31.," vol. 6, no. 1, pp. 13-31, 2015

[7] N. Sudarwati, "Developing an Integrated Module on Entrepreneurship to Improve Ability in," Int. J. Bussines, Humanit. Technol., vol. 3, no. 5, pp. 109-135, 2013.

[8] Depdiknas, Penulisan Modul. Jakarta: Depdiknas, 2008.

[9] BNSP, Model-Model Pembelajaran SMK. Jakarta: Depdiknas, 2008.

[10] A. Yulastri, H. Hidayat, Ganefri, S. Islami, and F. Edya, "Developing an Entrepreneurship Module by Using Product-Based Learning Approach in Vocational Education," Int. J. Environ. Sci. Educ., vol. 12, no. 5, pp. 1097-1109, 2017

[11] P. Willmot and G. Perkin, "Evaluating the effectiveness of a first year module designed to improve student engagement," Eng. Educ., vol. 6 , no. 2, pp. 57-69, 2011.

[12] R. M. Branch, Instructional Design: The ADDIE Approach. New York: Springer Science Business Media, LLC, 2009

[13] L. W. Anderson, A Taxonomy for Learning, Teaching and Assessing: A Revision of Bloom's Taxonomy of Educational Objective. New York: David Mckay Company, Inc, 2001. 
International Conference Asosiasi Pendidikan Teknologi dan Kejuruan Indonesia (APTEKINDO) 2018

[14] A. Syaifuddin, Realibilitas dan Validitas. Yogyakarta: Pustaka Belajar, 2014.

[15] Trianto, Mendesain Model Pembelajaran Inovatif-Progresif. Surabaya: Kencana Prenada Media Group, 2009. 